\author{
옥수수 가공형태와 RUP 수준이 전환기 젖소의 생산성에 \\ 미치는 영향 \\ 김현섭*.이종석**.김용국**.이왕식* \\ 농촌진흥청 축산연구소*, 충남대학교**
}

\title{
Influence of Corn Processing and Rumen Undegradable Protein Levels on Performance of Holstein Cows during the Transitional Period
}

\author{
H. S. Kim*, J. S. Lee**, Y. G. Kim** and W. S. Lee* \\ Dairy Cattle Division, National Livestock Research Institute, RDA* \\ Department of Dairy Science, Chungnam National University**
}

\begin{abstract}
This study examined the effect of corn processing with varying rumen undegradable protein (RUP) on feed intake, milk yield, its composition and, blood characteristics in Holstein cows during the transitional period ( 21 days pre partum to 21 days post partum). Twenty Holstein cows were randomly assigned to four diets (five cows/diet), ground corn with $30 \%$ RUP (GCR30), ground corn with $40 \%$ RUP (GCR40), flaked corn with $30 \%$ RUP (FCR30), and flaked corn with $40 \%$ RUP (FCR40). The processed corn with varying RUP was fed in total mixed rations (TMR) to cows. Dry matter intake (DMI) was higher with 40 $\%$ RUP diet than with $30 \%$ RUP diet, resulting in higher protein and energy intake by cows during pre and post partum $(\mathrm{p}<0.05)$. However, it was not affected by corn processing during pre and post partum. Similarly milk yield was higher with $40 \%$ RUP diet than with $30 \%$ RUP diet. and milk yield was affected by corn processing at RUP $30 \%$ level. Corn processing did not affected the milk fat and protein contents in dairy cows. The concentration of blood non esterified fatty acid (NEFA) were effected by RUP level with flaked corn, however, it was non-significant with RUP levels when given with ground corn. It is concluded that increasing RUP from $30 \%$ to $40 \%$ in iso-nitrogenous diet could increase milk yield in dairy cows during the transitional phase.
\end{abstract}

(Key words : Corn processing, Rumen undegradable protein, Milk production, Blood parameter, Dairy cow)

I. 서 론 6주간을 지칭한다. 젖소의 전환기동안에 TMR 형태로 사료를 급여하고, 옥수수를 가공 처리

젓소사양에서 전환기 (transition period)란 대 체적으로 임신말기에서부터 비유기로 이행되는 시기인 분만 3주전부터 분만 후 3 주까지의 약 하여 이용함으로서 에너지 섭취량을 최대로 증가 시키고, 건물 섭취량을 조절하여 (Hutjens, 1999) 분만 후 젖소의 사료섭취량을 많게 하고 유량,

Corresponding author : Hyeon-Shup Kim, National Livestock Research Institute, RDA, San-9, Eoryong-ri, Seonghwan-eup, Cheonan-si, Chungnam 330-801, Korea,

Tel. : 041-580-3380, E-mail : lrikhs@rda.go.kr 
유단백질, 유지방, $\mathrm{BCS}$, 체세포 수에 있어 유용 한 결과가 있음이 보고되었다 (Bertics 등, 1992 ; Studer, 1993).

여러 연구자들 (McAllan 등, 1984 ; McGuffey 등, 1990 ; Rajala-Schultz 등, 1999)은 분만전후 젖소의 사료 중 반추위 비분해성 단백질 (RUP : Ruminal undegradable protein)을 증가시킴으 로서 유량, 유단백질, 유지방 함량을 높이고, 대사성 질병인 케토시스 (ketosis), 유열(milk fever), 4위전위증 (left displaced abomasum) 및 후산정체 (retained placenta) 등의 감소에 영향 을 주었다고 보고하였으며, Doepel 등 (2002), Drackley (1999)와 Park 등(2002)은 전환기 젖 소의 사양관리에 따라 젖소의 생산능력 및 대사성 질병의 발생에 차이가 있었다고 보 고하고 있다. 사료 중의 단백질과 RUP 수준 이 전환기 젖소에 미치는 영향에 대한 조사에 서 Greenfield 등(2000)은 분만전 사료를 건물 기준으로 $\mathrm{CP} 12 \%$ 와 $\mathrm{RUP} 26 \%, \mathrm{CP} 16 \%$ 와 RUP $26 \%, \mathrm{CP} 16 \%$ 와 RUP $33 \%$ 혹은 $\mathrm{CP}$ $16 \%$ 와 RUP $40 \%$ 으로 급여하고, 분만 후에 모든 착유우에게 $\mathrm{CP} 18 \%, \mathrm{RUP} 40 \%$ 의 동일 한 사료를 급여하였을 때에 $\mathrm{CP} 12 \%$ 와 RUP $26 \%$ 의 사료를 급여하였던 젖소가 분만 후에 사료섭취량이 높고, 우유 생산량의 경우에도 높았다고 보고하였으나 혈액내 glucose, calcium, urea nitrogen, beta-hydroxybutyrate와 nonesterified fatty acids (NEFA) 에 있어서는 처리간에 차이 가 없었다고 보고하며, 임신 후반기에 $\mathrm{CP} 12$ $\%$ 와 RUP $26 \%$ 를 유지하는 것이 생산성에 유 리하다고 보고하고 있다. 그러나 이러한 결과 들에 대한 추가적인 검증이 필요한 것으로 사 료된다.

따라서 본 연구에서는 젖소에서 전환기 사양 방법으로서 곡류 가공 형태 및 RUP의 수준이 생산성에 미치는 효과를 구명하기 위하여, 분 만 후 젖소에게 파쇄 옥수수와 후레이크 처리 한 옥수수를 급여하면서 RUP 수준을 $30 \%$ 와 $40 \%$ 로 하여 사료를 급여하였을 때 젖소의 산 유 성적과 혈액 내 대사물질 수준의 변화를 조 사하였다.

\section{II. 재료 및 방법}

\section{1. 공시 동물 및 사양관리}

분만 전 Holstein종 젖소 경산우 20 두를 공시 하기 위하여 축산연구소에서 사육되고 있는 젖 소 중 전유기의 비유량과 현재의 유량, 산차 및 비유시기 등을 고려하여 유사한 능력을 가 진 착유우 20 두를 선발하여 처리구 당 5 두씩 개체별로 배치하여 사양시험을 수행하였고, 분 만전 8주부터 예비사양 후 분만 전 3주부터 분 만당일까지 처리별로 제조된 건유기 TMR 사료 를 자유 채식시켰으며, 분만이후에는 처리별로 제조된 착유기 TMR 사료를 급여하였다.

시험에 사용된 농후사료는 외국에서 수입된 옥수수 (황색)를 거칠게 파쇄하거나 후레이크 옥수수를 제조하기 위하여 스팀을 가하여 약 30 분정도 익힌 후에 두 개의 롤러사이를 통과

Table 1. Ingredient composition of compound feeds for cows during the dry period

\begin{tabular}{lcccc}
\hline \multirow{2}{*}{ Ingredient } & \multicolumn{4}{c}{ Treatments } \\
\cline { 2 - 5 } & GCR30 & GCR40 FCR30 FCR40 \\
\hline \hline Corn, ground & $\ldots \ldots \ldots \%$ of & DM $\cdots \cdots \cdots .$. \\
Corn, flaked & 42.2 & 42.2 & - & - \\
Wheat & - & - & 42.2 & 42.2 \\
Corn, gluten & 10 & 10 & 10 & 10 \\
Wheat bran & 4.5 & 4.5 & 4.5 & 4.5 \\
Rice bran, polished & 15.5 & 15.5 & 15.5 & 15.5 \\
Soybean meal & 4 & 4 & 4 & 4 \\
Soybean meal extrusion & 14 & 14 & - & - \\
Rapeseed meal & 3 & 1.5 & 3 & 1.5 \\
Fish meal & 0 & 1.5 & 0 & 1.5 \\
Molasses & 4 & 4 & 4 & 4 \\
Alfalfa pellet & 2 & 2 & 2 & 2 \\
Sodium bicarbonate & 0.3 & 0.3 & 0.3 & 0.3 \\
Vitamin mix.(Vit.A, D, E)* & 0.5 & 0.5 & 0.5 & 0.5 \\
\multicolumn{1}{c}{ Total } & 100 & 100 & 100 & 100 \\
\hline
\end{tabular}

* The vitamin mixture for the experimental diet provided the following per kilogram of diet : 3,000 IU of vitamin A, $400 \mathrm{IU}$ of vitamin $\mathrm{D}_{3}, 20 \mathrm{IU}$ of vitamin $\mathrm{E}$. 
Table 2. Ingredient composition of compound feeds for cows during the lactation period

\begin{tabular}{lrrrr}
\hline \multirow{2}{*}{ Ingredient } & \multicolumn{4}{c}{ Treatments } \\
\cline { 2 - 5 } & GCR30 & GCR40 & FCR30 & FCR40 \\
\hline \hline Corn, ground & $\cdots$ & \% & of DM & $\cdots \cdots$ \\
Corn, flaked & - & - & 40 & 40 \\
Soybean meal & 11 & 9.5 & - & - \\
Soybean meal extrusion & - & - & 11 & 9.5 \\
Rapeseed meal & 5 & 5 & 5 & 5 \\
Corn, germ & 10 & 10 & 10 & 10 \\
Corn, gluten & 8 & 8 & 8 & 8 \\
Wheat bran & 20 & 20 & 20 & 20 \\
Alfalfa pellet & 2 & 2 & 2 & 2 \\
Molasses & 2 & 2 & 2 & 2 \\
Fish meal & 0 & 1.5 & 0 & 1.5 \\
Monocalcium phosphate & 0.4 & 0.4 & 0.4 & 0.4 \\
Salt & 0.2 & 0.2 & 0.2 & 0.2 \\
Vitamin mix. (Vit.A, D, E)* & 0.5 & 0.5 & 0.5 & 0.5 \\
Sodium hydrogen carbonate & 0.4 & 0.4 & 0.4 & 0.4 \\
Calcium phosphate & 0.4 & 0.4 & 0.4 & 0.4 \\
Trace mineral mix.** & 0.1 & 0.1 & 0.1 & 0.1 \\
\multicolumn{1}{c}{ Total } & 100 & 100 & 100 & 100 \\
\hline$*$
\end{tabular}

* The vitamin mixture for the experimental diet provided the following per kilogram of diet : 3,000 IU of vitamin A, $400 \mathrm{IU}$ of vitamin $\mathrm{D}_{3}, 20 \mathrm{IU}$ of vitamin $\mathrm{E}$.

* The Trace mineral mixture for the experimental diet provided the following per kilogram of diet : $50 \mathrm{mg}$ of iron, $0.15 \mathrm{mg}$ of cobalt, $7 \mathrm{mg}$ of copper, $24 \mathrm{mg}$ of manganese, $30 \mathrm{mg}$ of zinc, $0.6 \mathrm{mg}$ of iodine, 0.15 $\mathrm{mg}$ of selenium.

시켜 납작하게 눌러 후레이크 곡물 형태로 가 공하여 이용하였으며, 그 외 단미사료는 가루 형태로 거칠게 분쇄하여 배합하였다.

시험구는 옥수수 가공처리 및 RUP 수준의 차이로 배치하였는데 처리 1 (GCR30)은 분쇄 옥수수에 RUP $30 \%$, 처리 2 (GCR40)는 분쇄 옥수수에 RUP $40 \%$, 처리 3 (FCR30)은 후레 이크 옥수수에 RUP $30 \%$ 그리고 처리 4 (FCR40)는 후레이크 옥수수에 RUP $40 \%$ 로 배합하여 급여하였다.

RUP $30 \%$ 는 대두박 (Soybean meal) 및 채종
박 (Rapeseed meal)을 이용하여 조정하고 RUP $40 \%$ 는 대두박 (Soybean meal extrusion)과 어 분(fish meal)을 이용하여 RUP 수준을 증량시 켰다.

시험사료의 배합비는 Table 1 과 Table 2에서 보여주는 바와 같으며, 배합사료의 영양소 함 량과 TMR의 배합비율 및 영양소 함량은 Table 3과 Table 4에 나타내었다.

Table 3. Ingredient composition of total mixed rations for cows during the dry period and lactation period

\begin{tabular}{lcc}
\hline \multirow{2}{*}{ Ingredient } & \multicolumn{2}{c}{ Period } \\
\cline { 2 - 3 } & Dry & Lactation \\
\hline \hline & $\cdots \cdots \cdots(\%$ of DM) & $\cdots \cdots \cdots$ \\
Compound feed & 24.4 & 49.0 \\
Corn silage & 51.5 & 31.7 \\
Mixed grass hay & 24.1 & 19.3 \\
$\quad$ Total & 100 & 100 \\
\hline
\end{tabular}

Table 4. Chemical composition of Total Mixed Rations

\begin{tabular}{|c|c|c|c|c|}
\hline \multirow{3}{*}{ Nutrients } & \multicolumn{4}{|c|}{ Treatment } \\
\hline & \multicolumn{2}{|c|}{ Dry period } & \multicolumn{2}{|c|}{$\begin{array}{l}\text { Lactation } \\
\text { period }\end{array}$} \\
\hline & $\begin{array}{l}\text { GCR30, } \\
\text { FCR30 }\end{array}$ & $\begin{array}{l}\text { GCR40, } \\
\text { FCR40 }\end{array}$ & $\begin{array}{l}\text { GCR30, } \\
\text { FCR30 }\end{array}$ & $\begin{array}{l}\text { GCR40, } \\
\text { FCR40 }\end{array}$ \\
\hline & \multicolumn{4}{|c|}{$\cdots \cdots \cdots \cdot(\%$ of $\mathrm{DM}) \cdots \cdots \cdots$} \\
\hline Dry Matter, (\%) & 38.3 & 38.3 & 49.1 & 49.1 \\
\hline $\mathrm{NEL}(\mathrm{Mcal} / \mathrm{kg}, \mathrm{DM})$ & 1.61 & 1.61 & 1.70 & 1.70 \\
\hline TDN & 74.5 & 74.5 & 75.4 & 76.0 \\
\hline Crude protein & 12.5 & 12.5 & 16.3 & 16.3 \\
\hline RUP $^{1)}$ & 3.75 & 4.99 & 4.89 & 6.52 \\
\hline RUP, $\%$ of $\mathrm{CP}$ & 30.0 & 39.9 & 30.0 & 40.0 \\
\hline $\mathrm{NDF}^{2)}$ & 56.1 & 56.1 & 46.9 & 46.9 \\
\hline $\mathrm{ADF}^{3)}$ & 33.1 & 33.1 & 26.4 & 26.46 \\
\hline Ether extract & 2.81 & 2.81 & 3.40 & 3.40 \\
\hline Ash & 7.04 & 7.04 & 5.91 & 5.91 \\
\hline Calcium & 0.23 & 0.23 & 0.47 & 0.47 \\
\hline Phosphorus & 0.17 & 0.17 & 0.4 & 0.4 \\
\hline
\end{tabular}

1) Rumen undegradable protein.

2) Neutral detergent fiber.

3) Acid detergent fiber. 


\section{2. 조사항목 및 조사방법}

분만 전 건유기와 착유기 TMR 사료를 하루 에 2회 12시간 간격으로 충분한 양을 급여하여 자유롭게 사료를 섭취할 수 있도록 하였고, 사 료급여 전에 남아있는 사료량을 칭량하여 사료 섭취량을 계산하였다.

착유는 1 일 2 회씩 실시하여 유량을 측정하였 으며, 우유시료를 채취하여 $\operatorname{LactoScope}^{\mathrm{R}}$ (MK2, Delta Instruments, The Netherlands)을 이용하여 유성분을 분석하였다.

혈액 샘플은 아침 착유가 끝나고 사료를 섭 취하기 전에 미근부에서 혈액을 채취하여 3,000 $\mathrm{rpm}$ 에서 15 분간 원심분리하여 혈장을 분리한 후 영하 $-20{ }^{\circ} \mathrm{C}$ 이하의 온도에서 보관하였다가, 혈 액생화학분석기 (Arco PC, Biotenica Instruments SPA, USA)에 의하여 NEFA, Glucose, Cortisol 및 Insulin의 농도를 측정하였다.

시험에 사용된 사료는 $1 \mathrm{~mm}$ mash screen이 장착된 시료분쇄기 (Cyclotec Sample Mill, Etecator, Sweden)로 분쇄하여 사용하였으며, 일반성분 분석은 $\mathrm{AOAC}$ (1990) 방법으로 분석하였고, $\mathrm{NDF}$ 와 $\mathrm{ADF}$ 함량은 Van Soest 등 (1991)의 방법으로 분석하였다.

그리고 본 시험에서 얻어진 결과는 $\mathrm{SAS}$ (1997) 통계프로그램을 이용하여 분석을 실시 하고, 평균 간의 차이는 Duncan의 Multiple Range Test를 이용하여 유의성 검정을 수행하 였다.

\section{III. 결과 및 고찰}

\section{1. 분만 전후 사료섭취량}

옥수수 가공형태 및 RUP 수준에 따른 건물 섭취량은 Fig. 1과 Table 5에서 보는 바와 같다. 분만 전 21 일의 사료섭취량은 건물기준으로 14 $\sim 15 \mathrm{~kg}$ 정도로 처리 간에 차이가 없었으며, 분 만 전 3일부터 사료섭취량은 급격한 감소를 보 이고 있다. 그러나 분만 후 3일부터 사료섭취 량이 증가하기 시작하였으며, 모든 처리구에서 분만 후 14 일에는 평균 사료섭취량의 $85 \%$ 정
도까지 회복되었다. 처리별 사료섭취량은 $\mathrm{FCR}$ 40 (옥수수후레이크 + RUP40 \%)와 GCR40 (옥수 수분쇄 + RUP40 \%) 처리에서 분만 전 섭취량이 $14.5 \mathrm{~kg}$ 및 $15.5 \mathrm{~kg}$ 으로 분만 후 섭취량은 17.1 $\mathrm{kg}$ 과 $16.4 \mathrm{~kg}$ 으로 RUP 수준을 $30 \%$ 로 하여 급 여하였던 처리구인 FCR 30 (옥수수후레이크+ RUP $30 \%$ ) 와 GCR 30 (옥수수분쇄 + RUP $30 \%$ )

Fig. 1. Changes in dry matter intakes (DMI) for cows fed diets containing ground or flaked corns with RUP $30 \%$ or RUP $40 \%$ during transitional phase

-GCR30 : Ground corn with RUP30 \% =GCR40 : Ground corn with RUP40\% - FCR30 : Flaked corn with RUP30\% - FCR40 : Flaked corn with RUP40\%

Table 5. Effect of treatments on feed intake and milk production for cows fed diets containing ground corn or flaked corn with RUP $30 \%$ and RUP $40 \%$

\begin{tabular}{lllll}
\hline \multirow{2}{*}{ Items } & \multicolumn{4}{c}{ Treatments } \\
\cline { 2 - 4 } & GCR30 GCR40 & FCR30 & FCR40 & SEM \\
\hline \hline
\end{tabular}

DMI, $\mathrm{kg} / \mathrm{d}$

$\begin{array}{llllll}- \text { Pre partum } & 13.9^{\mathrm{a}} & 15.3^{\mathrm{b}} & 13.8^{\mathrm{a}} & 14.5^{\mathrm{ab}} & 0.16\end{array}$

$\begin{array}{llllll}\text { - Post partum } & 14.7^{\mathrm{a}} & 16.4^{\mathrm{b}} & 14.7^{\mathrm{a}} & 17.1^{\mathrm{b}} & 0.77\end{array}$

$\begin{array}{llllll}\text { Milk yield, } \mathrm{kg} / \mathrm{d} & 32.9^{\mathrm{b}} & 36.4^{\mathrm{c}} & 25.4^{\mathrm{a}} & 36.5^{\mathrm{c}} & 0.51\end{array}$

$\begin{array}{llllll}4 \% \text { FCM, kg } & 32.9^{\mathrm{b}} & 35.0^{\mathrm{c}} & 25.4^{\mathrm{a}} & 35.7^{\mathrm{c}} & 0.56\end{array}$

$\begin{array}{llllll}\text { Milk fat, \% } & 4.0 & 3.8 & 4.0 & 3.9 & 0.07\end{array}$

$\begin{array}{llllll}\text { Milk protein, \% } & 3.4 & 3.1 & 3.4 & 3.3 & 0.036\end{array}$

${ }^{\text {abc }}$ Means in the same row with different superscripts are significantly different $(\mathrm{p}<0.05)$ 
에 비하여 사료섭취량이 유의하게 많게 나타났 다 $(\mathrm{P}<0.05)$. 분만 전 사료섭취량의 감소에 관 하여서는 다수의 연구자들이 비슷한 결과를 보 고하였는데 (Skaar 등, 1989 ; Bertics 등, 1992 ; Studer, 1993), 분만 전후의 사료의 건물섭취량 은 분만 3 주전부터 서서히 감소하다가 분만 1 주전부터 분만 시까지 약 $30 \%$ 정도의 급격 한 감소를 보이며, 분만 후 다시 약 3 주 동안 급격한 사료섭취량의 증가가 나타난다고 하였 다.

\section{2. 유량 및 유성분}

분만 후의 사료가공 형태와 RUP 증감에 따 른 유량 변화는 Table 5에 나타난 바와 같이, FCR40 처리에서 $17.1 \mathrm{~kg}$ 으로 가장 높았고, 이어 서 GCR40 처리에서 $16.4 \mathrm{~kg}, \mathrm{GCR} 30$ 처리에서 $14.7 \mathrm{~kg}$ 이며 FCR30에서 $14.7 \mathrm{~kg}$ 을 나타내었다. 여기에서 보여주는 바와 같이 옥수수의 가공형 태보다는 RUP 수준이 유량 증가에 큰 영향을 미쳐서, 반추위비분해단백질 수준을 높인 RUP $40 \%$ 처리구 (FCR40과 $\mathrm{GCR} 40$ )가 RUP $30 \%$ 처리구 (GCR30과 FCR30)에 비하여 유량 및 4 $\% \mathrm{FCM}$ 에 있어서 높은 결과를 보여 주었다 $(\mathrm{p}<0.05)$. 이러한 결과는 Mccormick 등 (1999) 이 비유초기의 단백질 급여에 있어서 단순하
게 단백질 수준을 높인 것과 단백질중의 RUP 함량을 높인 효과를 비교하는 연구에서 RUP 함량을 높인 처리에서 유량과 유지방, 유단백 질 등의 유성분 함량이 높았다고 보고한 결과 와 유사하였다.

\section{3. 분만전후의 처리구별 혈액내 대사물질 수 준의 변화}

분만 전후의 혈액 내 대사물질을 분석한 결 과는 Table 6에 나타낸 바와 같다. 분만전 - 후 의 NEFA의 농도를 보면 모든 처리구에서 분만 을 기점으로 NEFA 수준이 상승하였으며, 특히 분만 후에 유량이 높았던 FCR 40에서 NEFA 수준이 높게 나타났는데 $(\mathrm{p}<0.05)$ 이는 유량증 가에 비하여 분만초기에 사료섭취량이 충분하 지 못하여 체내에 축적되었던 지방이 유성분 합성에 이용되게 됨으로서 NEFA 함량이 증가 된 것으로 생각된다. Bertics 등 (1992)은 분만 전 젖소에게 강제급여에 의해 사료 섭취량을 증가시키더라도 분만 후에 $\mathrm{NEFA}$ 의 증가현상을 배제할 수 없었으며, 분만 전 사료섭취량이 떨 어지지 않은 소에 있어서도 분만 후에 NEFA 수준이 증가하였다고 보고하여 본 시험 결과와 부합되는 결과를 보여 주었다. 또한 Grummer (1995)는 분만 전에 에너지 수준이 높은 사료를

Table. 6 Plasma hormone and metabolite concentrations in cows fed diets containing ground corn or faked corn with RUP $30 \%$ and RUP $40 \%$ during the transitional period

\begin{tabular}{clccccc}
\hline & & \multicolumn{5}{c}{ Treatments } \\
\cline { 3 - 7 } Items & & GCR30 & GCR40 & FCR30 & FCR40 & SEM \\
\hline \hline \multirow{2}{*}{ NEFA, uEq/L } & Pre partum & 403.6 & 491.1 & 526.7 & 421.9 & 49.45 \\
& Post partum & $788.8^{\mathrm{ab}}$ & $938.9^{\mathrm{ab}}$ & $597.2^{\mathrm{a}}$ & $1,192.6^{\mathrm{b}}$ & 80.54 \\
\multirow{2}{*}{ Glucose, mg/dL } & Pre partum & $59.8^{\mathrm{a}}$ & $60.1^{\mathrm{a}}$ & $59.8^{\mathrm{a}}$ & $63.8^{\mathrm{b}}$ & 0.62 \\
& Post partum & 59.9 & 69.1 & 77.5 & 64.0 & 3.22 \\
Cortisol, ug/dL & Pre partum & 0.33 & 0.36 & 0.21 & 0.39 & 0.045 \\
& Post partum & 0.94 & 1.44 & 0.59 & 1.26 & 0.27 \\
Insulin, ulU/ml & Pre partum & 8.1 & 8.9 & 7.6 & 8.0 & 0.56 \\
& Post partum & $5.6^{\mathrm{a}}$ & $8.1^{\mathrm{a}}$ & $19.9^{\mathrm{b}}$ & $6.6^{\mathrm{a}}$ & 1.57 \\
\hline
\end{tabular}

abc Means in the same row with different superscripts are significantly different $(p<0.05)$ 
급여한 젖소에서 분만 후 1 일 이내에 간장내의 triglyceride 농도가 높은 경향이었고, 분만 후 혈장내의 NEFA 농도도 높았는데, 이러한 것 은 고 에너지 사료를 급여한 젖소들의 신체에 축적된 지방조직으로부터 지방산의 대사작용 이 증가하였다고 보고한 바 있다. 이러한 결 과들은 분만초기 젖소에 있어서는 사료섭취량 이 요구량에 비하여 충분하게 증가되지 않기 때문에 체내에 축적되었던 영양소의 이용에 의하여 우유생산을 유지하기 때문인 것으로 생각된다.

옥수수가공 처리 및 RUP 증감에 따른 혈액 내 glucose의 농도는 처리별로 유의한 차이가 없었으나 다른 처리에 비하여 옥수수를 후레 이크 형태로 가공하고 RUP 수준을 높였던 FCR40 처리에서 분만전에 유의하게 높은 농도 를 보여 주었다 $(\mathrm{p}<0.05)$. 손 등 (2003)이 옥수 수가공 처리에 의한 옥수수 분해 속도의 차이 를 조사한 결과에 의하면 후레이크 $(1.5 \mathrm{~mm}$ 및 $2.8 \mathrm{~mm}$ ) 처리된 옥수수의 분해율이 높아 빨리 분해되어 이용됨으로서 혈액 내 glucose 농도를 높일 수 있다고 보고하여 본 시험에서 얻어진 결과와 유사함을 알 수 있었다.

Cortisol 수준은 옥수수 가공처리 및 RUP 증 감 시험에 따른 처리 간에 유의한 차이가 없 었다. 여러 연구자들에 의하여 분만 전에 비하 여 분만 후에 cortisol이 높은 경향을 보여 주 었다고 보고하고 있으며 (Goff, 1996; Kaneene 등, 1996; Kehrli 등, 1989) 이러한 것은 분만 전에 비하여 분만 후에 젖소의 스트레스 증가 에 의한 것이라고 보고하고 있어 처리의 효과 에 대하여 종합적으로 검토할 필요가 있을 것 으로 생각된다.

옥수수 가공형태와 RUP 증감에 따른 insulin 농도는 분만 전에 처리에 따른 차이가 없으나, 분만 후에 FCR 30 처리에서 유의하게 높은 농 도를 보여 주었다 $(\mathrm{p}<0.05)$. 이는 혈액 내에 glucose 수준이 높았던 결과와 사료섭취량을 반 영하는 결과로 생각할 수 있었다.

$$
\text { IV. 요 약 }
$$

본 연구는 젖소에서 곡류의 가공형태 및 RUP수준이 효과를 구명하기 위하여 분만 전 3 주부터 분만 후 3 주까지 전환기 Holstein 종 경산우 20 두(4처리 5 반복)에게 $\mathrm{TMR}$ 사료를 GCR30 (파쇄옥수수 + RUP $30 \%$ ), GCR40 (파 쇄옥수수 + RUP40 \%), FCR30 (후레이크옥수 수 + RUP $30 \%$ ), FCR40 (후레이크옥수수+ RUP $40 \%$ )로 하여, 건유기와 비유기로 구분 하여 배합하여 급여하였다. 본 연구로부터 얻 어진 결과를 요약하면 다음과 같다.

분만전 사료의 건물 섭취량은 처리별로 평 균 $14 \sim 15 \mathrm{~kg}$ 이었으며, 건유기간 중 사료섭취 량에는 유의한 차이가 없었으나, 분만 후 건물 섭취량에서는 RUP $40 \%$ 에서 섭취량이 RUP 30 $\%$ 보다 높게 나타났다 $(\mathrm{P}<0.05)$.

유량은 RUP $40 \%$ 사료를 급여한 구 (FCR40 과 GCR40)에서 유의하게 높은 결과를 보여주 었다.

유단백질과 유지방을 분석한 결과, 유지방에 있어서는 옥수수 가공 형태인 후레이크와 파쇄 처리에 따른 유의있는 결과를 보여주지는 않았 다.

혈액 내 대사물질은 분만 전에 비하여 분만 당일의 수치가 모든 처리에서 상승하는 것을 볼 수 있었으며, 분만전 - 후의 $\mathrm{NEFA}$ 의 농도를 보면 모든 처리구에서 분만을 기점으로 상승하 였으며, 특히 분만 후에 유량이 높았던 FCR40 에서 NEFA 수준이 전반적으로 높은 경향을 보 였다 $(\mathrm{p}<0.05)$. Glucose와 cortisol 수준은 포도당 농도에서 FCR40구의 건유기가 다른 구보다 유의하게 높았으나 타 처리구간에서는 유의 차가 인정되지 않았다. Insulin 농도에 있어서 도 분만 전에 처리 간에 유의한 차이가 없으 나, 분만 후에는 타처리와 비교하여 FCR40 처리에서 유의하게 높은 농도를 보여 주었다 ( $<<0.05)$.

이 시험에서는 옥수수의 가공형태보다는 동 량의 단백질에 RUP 함량을 $30 \%$ 에서 $40 \%$ 로 
증가시킴으로서 에너지, 단백질 이용 효율을 높여 젖소의 생산성을 높일 수 있을 것으로 생 각된다.

\section{$\mathrm{V}$. 인 용 문 헌}

1. AOAC. 1990. Official Methods of Analytical Chemists. Washington, D. C.

2. Bertics, S. J., Grummer, R. R., Cadorniga-Valino, C. and Stoddard, E. E. 1992. Effect of prepartum dry matter intake on liver triglyceride concentration and early lactation. J. Dairy Sci. 75:1914-1922.

3. Doepel, L., Lapierre, H. and Kennelly, J. J. 2002. Peripartum performance and metabolism of dairy cows in response to prepartum energy and protein intake. J. Dairy Sci. 85:2315-2334.

4. Drackley, J. k. 1999. Biology of dairy cows during the transition period: The final frontier? J. Dairy Sci. 82:2259-2273.

5. Greenfield, R. B., Cecava, M. J., Johnson, T. R. and Donkin, S. S. 2000. Impact of dietary protein amount and rumen undegradability on intake, peripartum liver triglyceride, plasma metabolites, and milk production in transition dairy cattle. $\mathrm{J}$ Dairy Sci. 83(4):703-10.

6. Grummer, R. R. 1995. Impact of changes in organic nutrient metabolism on feeding the transition dairy cow. J. Anim. Sci 73:2820-2833.

7. Goering, H. K. and Van Soest, P. J. 1970. Forage fiber analysis (apparatus, reagents, procedures and some application). Agric. Handbook 370. USDA. ARS. Washington, DC.

8. Goff, J. P. 1996. Transition cow diet : A Chance to reduce metabolic disease. Dairy Report - Iowa state university DSL - 96.

9. Hutjens, M. 1999. Effect of corn processing on milk performance, dry matter intake, and weight change. www. Illinois-traill @ uiuc. edu. Illini DairyNet: Paper Collection: Dairy Days - 1999

10. Kaneene, J. B., Miller, R. A., Herdt, T. H. and Gardiner, J. C. 1996. The association of serum nonesterified fatty acids and cholesterol, manage- ment and feeding practices with peripartum disease in dairy cows. Pre. Vet. Med. 31:59-72.

11. Kehrli, J. R., Nonnecke, B. J. and Roth, J. A. 1989. Alterations in bovine neutrophil function during the periparturient period. Am. J. Vet. Res. 50:207-214.

12. McAllan, A. B. and Smith, R. H. 1984. The efficiency of microbial protein synthesis in the rumen and the degradability of nitrogen between the mouth and abomasum in steers given different diets. Br. J. Nutr. 51: 77-83. J. Dairy Sci. 82: 2697-2708.

13. McCormick, M. E., French, D. D., Brown, T. F., Cuomo, G. J., Chapa, A. M., Fernandez, J. M., Beatty, J. F. and Blouin, D. C. 1999. Crude protein and rumen undergradable protein effects on reproduction and lactation performance of Holstein cows. J. Dairy Sci. 82:2697-2708.

14. McGuffey, R. K., Green, H. B. and Basson, R. P. 1990. Lactational response of dairy cows receiving bovine somatotropin and fed rations varying in crude protein and undegradable intake protein. J. Dairy Sci. 73:2437-2443.

15. Park, A. F., Shirley, J. E., Trigemeyer, E. C., Meyer, M. J. and Vande, Haar, M. J. 2002. Effect of protein level in prepartum diets on metabolism and performance of dairy cows. J. Dairy Sci. 85:1815-1828.

16. Rajala-Schultz, P. J., Grohn, Y. T. and McColloch, C. E. 1999. Effects of milk fever, ketosis, and lameness on milk yields in dairy cows. J. Dairy Sci. 82:288-294

17. SAS. 1997. SAS User's Guide : Statistics. SAS Inst., Inc., Cary. NC.

18. Skaar, T. C., Grummer, R. R., Dentine, M. R. and Stauffacher, R. H. 1989. Seasonal effects of prepartum and postpartum fat and niacin feeding on lactation performance and lipid metabolism. J. Dairy Sci. 72:2028-2038.

19. Studer, C. A., Grummer, R. R. and Bertics, S. J. 1993. Effects of prepartum propylene glycol administration on periparturient fatty liver in dairy 
Kim et. al. ; Effect of Corn Processing and RUP Levels on Performance of Dairy Cows

cow. J. Dairy Sci. 76:2931-2939.

20. Van Soest, P. J., Robertson J. B. and Lewis. B. A. 1991. Methods for dietary fiber, neutral detergent fiber and non-starch polysaccharides in relation to animal nutrition. J. Dairy Sci. 74:3583-3597.
21. 손근남, 김용국, 이수기, 김현섭. 2003. 옥수수의 가공 방법이 in sacco 전분 및 단백질 분해율에 미치는 영향. 한국동물자원과학회지 45(3):421432.

(접수일자 : 2005. 10. 6. / 채택일자 : 2005. 12. 13.) 